\title{
Article
}

\section{Examining the Spatial Coordination between Metrorail Accessibility and Urban Spatial Form in the Context of Big Data}

\author{
Jingming Liu ${ }^{1}$, Xianhui Hou ${ }^{2, * \mathbb{D}}$, Chuyu Xia ${ }^{3}$, Xiang Kang ${ }^{1}$ and Yujun Zhou ${ }^{1}$ \\ 1 School of Public Policy and Administration, Xi'an Jiaotong University, Xi'an 710049, China; \\ jimmyliu1993@stu.xjtu.edu.cn (J.L.); Kangxiang9523@stu.xjtu.edu.cn (X.K.); \\ zhou20191202@stu.xjtu.edu.cn (Y.Z.) \\ 2 College of Economics and Management, Northwest A\&F University, Yangling 712100, China \\ 3 School of Environment, Beijing Normal University, Beijing 100875, China; chuyu.xia@bnu.edu.cn \\ * Correspondence: houxh2017@nwafu.edu.cn
}

check for updates

Citation: Liu, J.; Hou, X.; Xia, C.; Kang, X.; Zhou, Y. Examining the Spatial Coordination between Metrorail Accessibility and Urban Spatial Form in the Context of Big Data. Land 2021, 10, 580. https:/ / doi.org/10.3390/land10060580

Academic Editor: Jefferey M. Sellers

Received: 28 April 2021

Accepted: 28 May 2021

Published: 31 May 2021

Publisher's Note: MDPI stays neutral with regard to jurisdictional claims in published maps and institutional affiliations.

Copyright: (c) 2021 by the authors. Licensee MDPI, Basel, Switzerland. This article is an open access article distributed under the terms and conditions of the Creative Commons Attribution (CC BY) license (https:// creativecommons.org/licenses/by/ $4.0 /)$.

\begin{abstract}
Metrorail accessibility is an important indicator that influences urban spatial form. For this article, we created a 3SFCA method to analyze the Metrorail accessibility of Shanghai covering four levels: traffic analysis zones (TAZs), stations, metrorail network, and regions. The floor area ratio (FAR) was used to reflect the urban form, and spatial coordination model was introduced to examine the spatial balance between metrorail accessibility and urban forms. Results revealed that the spatial distribution of metrorail accessibility and urban form are characterized by a monocentric spatial structure, while the values of both variables decrease gradually from urban center to suburban regions, with the regional difference being significantly greater than the other three levels. The results also indicated that the development of metrorail stations has a time lag effect on the urban spatial form, and the catchment area of a metro station shows characteristics of gradually expanding and then shrinking from city center to suburban regions. Finally, the results showed that there is a strong coordination between accessibility and urban form around metro stations, but the coordinate degree varies by regions. Thus, we concluded that station density should be increased within the fourth ring, FAR should be increased between the second and third rings, and rail transit capacity in the urban center area should be increased.
\end{abstract}

Keywords: metrorail accessibility; urban spatial form; 3SFCA model; spatial coordination; Shanghai

\section{Introduction}

Transportation is a direct product forced by spatial decentralization and concentration [1], and is also an effective tool for the spatial development and redevelopment of the urban form [2]. Transport networks serve to increase accessibility between regions and to expand the range of cities by improving time efficiency, which plays a key role in the development of the urban form and urban regeneration [3,4]. However, with the excessive spread of cities, the conflicts between increased population density, frequent social activities, and outdated road traffic planning emerge [5], causing traffic congestion, increased associated carbon emissions, and increased demand for roadway capacity [6]. To address these problems, policy-makers focus on reducing automobility, pushing alternative sources of energy, increasing speed control mechanisms, and encouraging public transport and other management measures [7,8]; however, this involves ignoring the derived demand of the social exchange around destination stations $[9,10]$, which is closely related to the performance of transport network, land use density, urban form, as well as the number of opportunities available near the stations [11].

Metrorail networks provide significant emerging opportunities and link various parts of a city. Metro stations, on the other hand, are regarded as both a major node of the transportation network and physical urban network [12]. So, the majority of commercial and residential facilities choose to be near subway stations so that it is easier for individuals 
to reach destinations where they can meet their daily needs [11]. Metrorail accessibility focuses on making it easier for individuals to reach destinations [13], taking the benefits from both transportation and land-use decisions into account [14]. For example, mixing and densifying the use of urban land areas could bring functional origins and destinations together [15], leading different neighborhoods, streets, and metro catchment areas to be more accessible by increasing travel-time savings and facilitating longer travel [16]. However, regional transport policy approaches are often focused on congestion and the mobility of private cars, but not on public transport accessibility. These approaches ignore consistency between transport plans and regional land use plans [17]. Therefore, how to analyze the coordination degree between metrorail travel demand, travel capacity, and urban form from the perspective of individuals is the key question for this paper and is particularly important to coordinate the development of an urban rail network and urban form.

Transit-oriented development (TOD) seeks to maximize facility accessibility through mass transit with centrally located rail or bus stations surrounded by relatively highdensity commercial and residential developments [18]. TOD has been recognized as the most effective way for urban planners to solve problems such as traffic congestion, air pollution, inefficient use of energy and time, and socially unequal accessibility in metropole cities, generating substantial operating profits in locations like Hong Kong and Singapore [19]. Most rapidly growing cities in mainland China hope to learn from these cities, but unlike Hong Kong's urban planning regulations, there are too many land areas near these cities' stations that have been occupied or planned but have not been built-up, and the construction of the stations was not based on the travel demand of the individuals and the transport capacity of the railway systems, but on the need for urban expansion [20]. Therefore, measuring the consistency between land plans of built-up areas with transportation demand plays a significant role in the location of TOD programs and the improvement of urban land-use efficiency.

Current accessibility calculations have too many assumptions; they evaluate the performance of railway services by using a cost-distance tool within a fixed distance or time threshold [21,22]. In general, the catchment area of stations is restricted to $800 \mathrm{~m}$ around the station or 40 minutes of total travel time from a place to any target point on the railway network [21]. Even though this measure is efficient to operate, it ignores the differences in individual behaviors and the derived demand for rail transit $[9,10]$. The calculations only consider the performance of the railway network or the spatial balance of the station's densities separately, ignoring the connection between the railway network and the roadway network [22]. The following three steps were used to evaluate accessibility for this article. To begin, we computed the supply-to-demand ratio for each station by counting commuters and measuring the carrying capacity. Then, by introducing passenger flow weight indicators, we measured the BTA (By transit accessibility) value for each station. Finally, we used a distance decay method to assess the metrorail accessibility of each TAZ within Shanghai's third ring. Compared with the current method, this paper uses a large amount of data from the perspective of travel behavior, which not only reflects the accessibility for different stations and Traffic analysis zones (TAZs), but also connects the rail transit system with road systems. This accessibility value could provide distinct recommendations for different regions. Due to the long life of urban structures, the spatial form of a city will have a long-lasting social-economic and environmental impact on accessibility, related emissions, and livability [23]. The improvement of build-up area and urban functions within the catchment of a subway not only reduces traffic demand between units and strengthens the combination between different traffic modes [24], but it is also critical for promoting urban mixed land use and forming a station-centric urban design [25]. In response to these needs and weaknesses, this article primarily addresses the following questions:

(1) How should the metrorail accessibility of each traffic analysis zone be evaluated from the perspective of transportation integration? 
(2) What are the spatial characteristics of the metrorail transit system and urban spatial form?

(3) Is the existing metrorail accessibility consistent and coordinated with the urban spatial form?

To address the above three issues, we first created the 3SFCA model from the perspectives of travel behavior and transportation integration to evaluate the accessibility of TAZs near subway stations in Shanghai. Second, based on existing building floor and spatial distributions of building infrastructure in Shanghai, the spatial morphological characteristics of land use around rail transit stations were examined. Finally, we evaluated the degree of spatial coordination between metrorail accessibility and urban spatial form in Shanghai by using the spatial coordination model. Based on the results of the analysis, we aimed to provide policy suggestions to policymakers for realizing the guiding role of the rail transit system in urban development, as well as implementing the TOD programs and improving urban land functions.

\section{Literature Review}

\subsection{Transportation Accessibility}

Existing literature considers that accessibility refers to the convenience of participating in various activities and receiving the necessary services from one place. The distribution of opportunities and traffic conditions are the key factors to determining accessibility [26]. Li divides the existing accessibility calculation methods into four categories, namely: revealed accessibility based on geographic access, revealed accessibility based on social statistics, potential accessibility based on geographic access, and potential accessibility based on social statistics [27]. The commonly used methods for calculating accessibility using geospatial methods are: Space-time measures [28-30]; A mathematical formulation-based approach [31-33]; a gravity-based method [34,35]; and origin-destination measures [36,37]. Meanwhile, social statistical methods for accessibility calculations include: RP/SP survey based statistical analysis [38-40]; Activity based analysis [41]; and Social and economic analysis [42].

However, due to the functional differences between public facilities, the selection of accessibility methods differs, and the research unit also differs. The most common accessibility assessment methods are primarily based on supply and demand theory, such as the gravity model or 2-step floating catchment zone (2SFCA) model, which identifies medical accessibility within pre-defined and arbitrary administration [43]. Unlike health care, green service, and other public facilities, the accessibility of public transportation depends not only on the accessibility to the stations, but also on the convenience for individuals to reach a destination through metrorail systems, so its evaluation method is generally divided into two steps, namely "to transit accessibility (TTA)" and "by transit accessibility (BTA)" [44]. TTA is mainly used to assess the ease of reaching stations. The service scale mainly depends on physical factors, such as walking time (distance), the number of other alternative transportation vehicles around a station, physical features of transit facilities (such as its location, size, coverage, etc.), and the number of intersections which should be passed through to get to the transit station [45]. The evaluation method of BTA mainly considers the convenience for individuals to participate in various activities [46]. However, current research always confuses TTA and BTA, or treats one of them as the value of metro accessibility assessment, despite the two concepts being different $[47,48]$. Generally, the evaluation indicators of TTA are indicated by a station's catchment area, also known as the buffer area, which constrains accessibility for peripheral citizens [49]. The distance to stations is the TTA evaluation range, and the calculation of BTA generally indicates the performance of the commuting efficiency by calculating commuting costs or the time spent for different distances or time thresholds [50].

Despite this, the following deficiencies still exist. First of all, the BTA calculation method has to adopt the time threshold or distance threshold, which undoubtedly fails to assess the reachability of long-distance activities in the evaluation process. Secondly, in the 
past, because of the restriction of research data, scholars only analyzed the efficiencies based on pre-defined and arbitrary administrative boundaries, but the frequent interaction of social urban activities has already broken across these boundaries. Lastly, when measuring a station's commute efficiency, a single accessibility value does not represent the disparity in supply and demand between different stations and TAZs.

To address the limitations of existing research, we modified the traditional 2SFCA model by considering both TTA and BTA measurements. In the calculation of TTA, we treated the traffic analysis zone within $2 \mathrm{~km}$ around the stations as the basic analysis zone, and used the distance decay function to calculate the accessibility of each analysis zone. The BTA calculation measured the accessibility of commuters from the station to destination stations without the limitations of time or financial cost. In accordance with the disparity between passenger choice on various routes, the weight index was assigned, which finally balanced the supply of transit service and demand for commuting trips in the different stations.

\subsection{Metrorail Accessibility and Urban Spatial Form}

According to the theory of urban location, households or firms bid for locations by trading housing and land consumption against commuting costs to the urban center of a city; in addition, while travel behavior is influenced by urban spatial patterns, accessibility determines the value of land [51-53]. As a result, the accessibility of urban transportation infrastructure determines how urban land is developed and has an impact on future urban land use decisions [54]. However, the relationship between urban land use and transportation shows variations in different regions.

Due to the prevalence of private cars, road traffic has an enormous economic impact on urban spatial form in developed countries such as the United States, and a large part of the impact comes from the transferred income of road profitability [55], thereby increasing the economic agglomeration effect; however, encouraging infrastructure incomes to be re-supplied to different entities is key to achieving this. In the largest metropolitan areas, however, the transportation and highway network led to low-density suburban and exurban sprawl extending 30-40 miles from the traditional central business districts (CBDs) [56], and the investment in public transport, such as urban railways, does not have a significant impact on suburban economic growth in these cities [57].

In developing countries, particularly countries with a high population density like China and India, if we could coordinate the relationship between transportation and urban form well, then the natural environment will be improved, while the living quality of less affluent citizens and long-term economic prosperity will also be improved [58]. Compared with private transportation, public transportation investment has a significant role in promoting a city's economic endogenous growth [2]. In addition, the high density of land-use and high-rise buildings would also affect transport, for example (1) by reducing travel costs, (2) facilitating public transport instead of cars, and (3) removing or shortening vehicle traffic by attracting people to convenient destinations for different purposes $[59,60]$.

Accessibility not only takes into account driving conditions of public transportation but also pays attention to people's access to public mobility facilities [61]. Accessibilitybased research extends the possible solutions to transport problems, including improved transportation and more efficient land use patterns, to reduce travel distances [61]. A particularly important approach to solving urban transport issues is to shift patterns of land use through transit-oriented development. TAZ was developed to form hierarchical groups of mutually exclusive subsets on the basis of their similarity with respect to specified characteristics [62]. For building structures and transport networks, the structure and network of TAZs are closely related to the travel behavior and the urban form [63]. Several studies have also shown that land use patterns measured at different geographic resolutions can produce different empirical estimates [64].

The transit-oriented urban development model encourages multiple transportation models, such as walking, bicycling, and buses, which plays an important role in promoting 
a city's rational development by forming a high-density, mixed-use, and compact urban development model [2]. However, the impact of rail transit accessibility on urban morphology varies by region. This is primarily due to the close relationship between people's rail transit travel needs in different regions and the density of opportunities around stations [65]. Therefore, what is the scope of influence of rail transit stations in different regions on the urban spatial form and how to achieve spatial fairness for metrorail accessibility within a region are the main factors that affect future urban development.

But little attention has been paid towards addressing these issues. As fine-grained data about land use and travel activity has become available, this paper proposed to analyze the coordination relationship between urban spatial form and accessibility at TAZs levels by using the spatial coordination development model. To compare the degree of coordination between different regions, we divided the walk distance around a station into five categories: $500 \mathrm{~m}, 800 \mathrm{~m}, 1000 \mathrm{~m}, 1500 \mathrm{~m}$, and $2000 \mathrm{~m}$, and provided suggestions for implementing TOD programs.

\section{Data and Study Area}

With the degree of urbanization increasing rapidly, the importance of urban rail transit to the development of the city has gradually become prominent. Shanghai, China's largest metropolis, has taken the lead in improving the country's railway [2]. Taking Shanghai as a research area to estimate the spatial coordinate degree between rail transit accessibility and land use is important for supporting rail transit planning and urban development in other cities. The urban metrorail network is the most important component of the Shanghai rail transit system, which is the country's largest by station numbers and the largest by length of the tracks. By the end of 2020, 16 lines with 344 stations were operated and the total length reached $669.5 \mathrm{~km}$, while the average ridership was 10.63 million passengers per day. There are 61 transfer stations in Shanghai, accounting for $15.25 \%$ of the total number of stations [66]. We took the ridership from one holiday and two workdays in 2018 as case studies to analyze the daily behavior of passengers in Shanghai.

Because of the large size of the administrative district, it is not possible to reflect the heterogeneity of the coordinate degree between land use and accessibility at the levels of traffic analysis zones (TAZs), stations, and the metrorail network. Therefore, we introduced the concept of traffic analysis zones [67] and divided the area within the Fourth Ring into 16,148 parcels based on Shanghai's primary and secondary roadway network. The characteristics of land use and rail transit in the same transportation area are homogeneous, and the size of TAZ is small, which are conducive to the adjustment of policy implementation.

Considering that $2 \mathrm{~km}$ is the longest distance for a rail transit service in the current literature, we thus treated $2 \mathrm{~km}$ as the distance threshold and selected 5270 units around the stations as the final research parcels [22]. The data source description is shown in Table 1. As of 2018, Shanghai has a total of 387 stations. Due to the available data, the passenger flow of 344 stations was evaluated, while the urban spatial form was calculated by using the floor area ratio (FAR).

Based on the differences in the spatial distribution of subways and urban construction, from the first ring to the fourth ring, the proportions of the area covered by stations within $2 \mathrm{~km}$ of the total area are 87.68 percent, 76.25 percent, 64.34 percent, and 42.38 percent, respectively, showing a gradually decreasing trend from the city center to the suburbs. In comparison with holidays, the number of passengers on a workday is relatively smaller, while the distribution of passenger flows in inner-city districts are more highly concentrated compared to the suburban areas, shown as short-distance high frequency commuting characteristics (Figure 1). During the holidays, the Shanghai traffic spreads to the suburbs, with long distance and low frequency traffic characteristics. On a holiday there are 933 routes for over 1000 people in a day and 788 routes on workdays. But, on either workdays or holidays, the majority of high-frequency stations are transfer stations, such as the Shanghai train station and Hongqiao train station. 
Table 1. Description of data sources.

\begin{tabular}{|c|c|c|c|c|}
\hline Field Name & Amount & Variables & Data Source & Year \\
\hline \multirow{4}{*}{$\begin{array}{cc} & \text { M Workday } \\
\text { D } & \text { N Workday } \\
\text { Holiday } \\
\text { Shanghai Road Map }\end{array}$} & $7,245,131$ & & \multirow{3}{*}{ shmetro.com } & \multirow{8}{*}{2018} \\
\hline & $7,297,484$ & Departure station; Departure route; & & \\
\hline & $8,200,763$ & Destination Station; Destination route; Counts & & \\
\hline & 81,599 & Road level; Name; Length & udparty.com & \\
\hline & & Line Routes; Time Schedule; Station name; & & \\
\hline Metro Station & 344 & $\begin{array}{l}\text { Location; Length; Transfer Station name; } \\
\text { Average time interval; Capacity; }\end{array}$ & udparty.com & \\
\hline Floor to Area ratio & 618,415 & Stories; Land Area; Build area; Location & udparty.com & \\
\hline Parcels & 5270 & ID; Land Area & udparty.com & \\
\hline
\end{tabular}

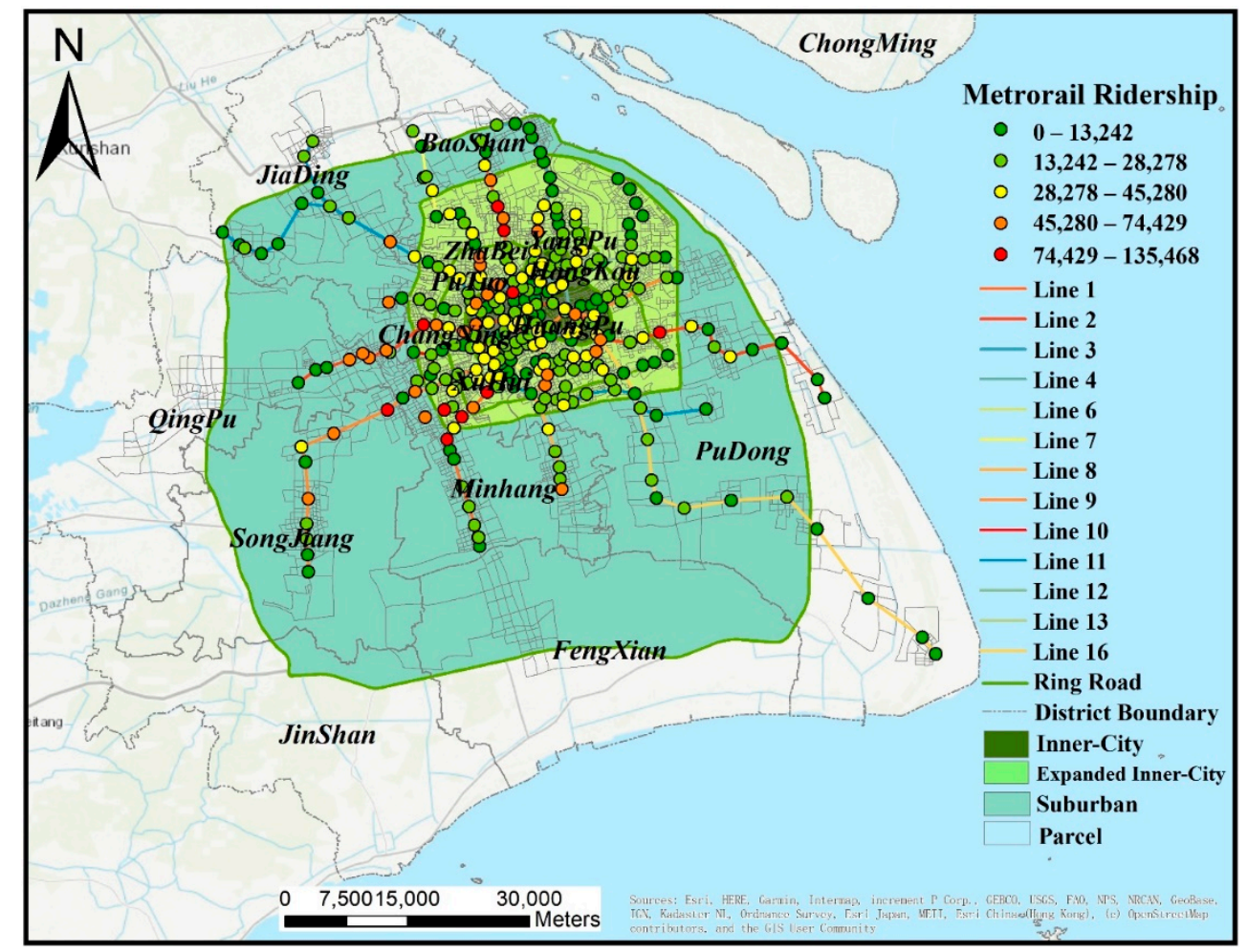

Figure 1. Metrorail Ridership on a workday in Shanghai.

\section{Methodology}

Our method was based on three methods: The two-step floating catchment area (2SFCA) method, gravity model, and the cumulative opportunity measure $[26,34,68]$. The major difference between 3SFCA and 2SFCA models is the research unit. The 2SFCA models do not have access to locations outside the catchment area and the research unit of 2SFCA models is based on the rail stations but not the neighborhoods. Current research calculates the accessibility of neighborhoods by using distance decay of the gravity model [69], but this model not consider the supply side of the railway service. Thus, the current research calculated the accessibility of each parcel by the following three steps: (1) Calculate the value of BTA for each station; (2) Calculate the value of TTA for each TAZ; (3) Integrate the above two values by the distance decay model. In general, the 3SFCA approach better calculates the accessibility from each parcel to any destination stations across the city. Finally, we introduced the coupling model to analyze the degree of correlation between the accessibility of metrorail and the urban spatial form in Shanghai. 


\subsection{SFCA Method for Accessibility Calculation}

The 2SFCA method is widely used in key health performance measures, as it calculates the accessibility by a physician-to-population ratio [70]. But the metrorail accessibility is different from that of a healthcare facility, as the metro station is the link between the neighborhood and the destination stations; thus, we needed to consider both the TTA and BTA at the same time. Based on the traditional 2SFCA and related research results [71], this paper proposes a new method for evaluating transit accessibility. This method is the extended 2SFCA model - 3SFCA method, which includes the next three steps.

Step 1: Calculation of the supply-to-demand ratio of a destination station. In this step, the supply of destination station refers to the passenger carrying capacity of all the vehicles passing through this point (the station), The function of metro vehicles scheduled, vehicle sizes [71], and the demand can be calculated by the total number of passenger arrivals in station $j$, while the supply-to-demand ratio $R_{j}$ for the destination station can be calculated as follows:

$$
R_{j}=\frac{S_{j}}{D_{j}}
$$

where:

$R_{j}$-Supply-to-demand ratio $R_{j}$;

$j$-index of the supply point (destination station);

$D_{j}$ - the total number of passenger arrivals in station $j$;

$S_{j}$ - the passenger carrying capacity of $j$ station for one day.

Step 2: Calculation of BTA of the departure station. In the traditional 2SFCA method, the accessibility of a neighborhood is the summation of all supply-to-demand ratios from the supply points within its catchment area. However, the catchment area for different stations varies, as the transit capacity for each station and the population density near each station is different, and the 2SFCA method also ignores the long-distance travel demand. Therefore, the weight value $W_{k j}$ used for this research was the ratio of the number of passengers arriving at destination station $j$ from departure station $k$ to the total number of passengers arriving at station $j$. Figure 2 shows the methodology framework for BTA, and the formula for the BTA of the departure station is:

$$
T_{k}=\sum_{k j=1}^{n} R_{j} \times W_{k j}=\sum_{k j=1}^{n}\left(\frac{S_{j}}{D_{j}} \times \frac{D_{k j}}{D_{j}}\right), W_{k j}=\frac{D_{k j}}{D_{j}}
$$

where:

$k$-index of the demand point (departure station);

$W_{k j}$ - the weight value of the demand, calculated by the ridership departure from $k$ station to $j$ station;

$T_{k}$-BTA value of departure station $k$; for this paper, we took this value as the attractiveness of the station. Other notations are the same as in Equation (1);

$n$-the total number of routes that depart from $k$ station.

Steps 3: The core of Cumulative Accessibility is the sum of potential of opportunities for individuals [68]. Also, the gravity model is based on the universal law of gravitation and is the most frequently used model to analyze accessibility. Since different traffic environments surround different traffic analysis zones, passengers can reach rail transit stations via walking, bus, shared bicycles, or other modes of transportation. However, for the current study, the majority of stations' catchment areas are within $2 \mathrm{~km}$ of those stations. As the attractiveness of the departure station is higher and the distance is closer, the metrorail accessibility for the relevant parcels is higher.

$$
A_{i}=\sum_{k} T_{k} f\left(c_{i k}\right)
$$

$A_{i}$-metrorail accessibility of zone $i$; 
$T_{k}$ - the attractiveness of departure station $k$, is same as the Equation (2);

$f\left(c_{i k}\right)$-distance decay.

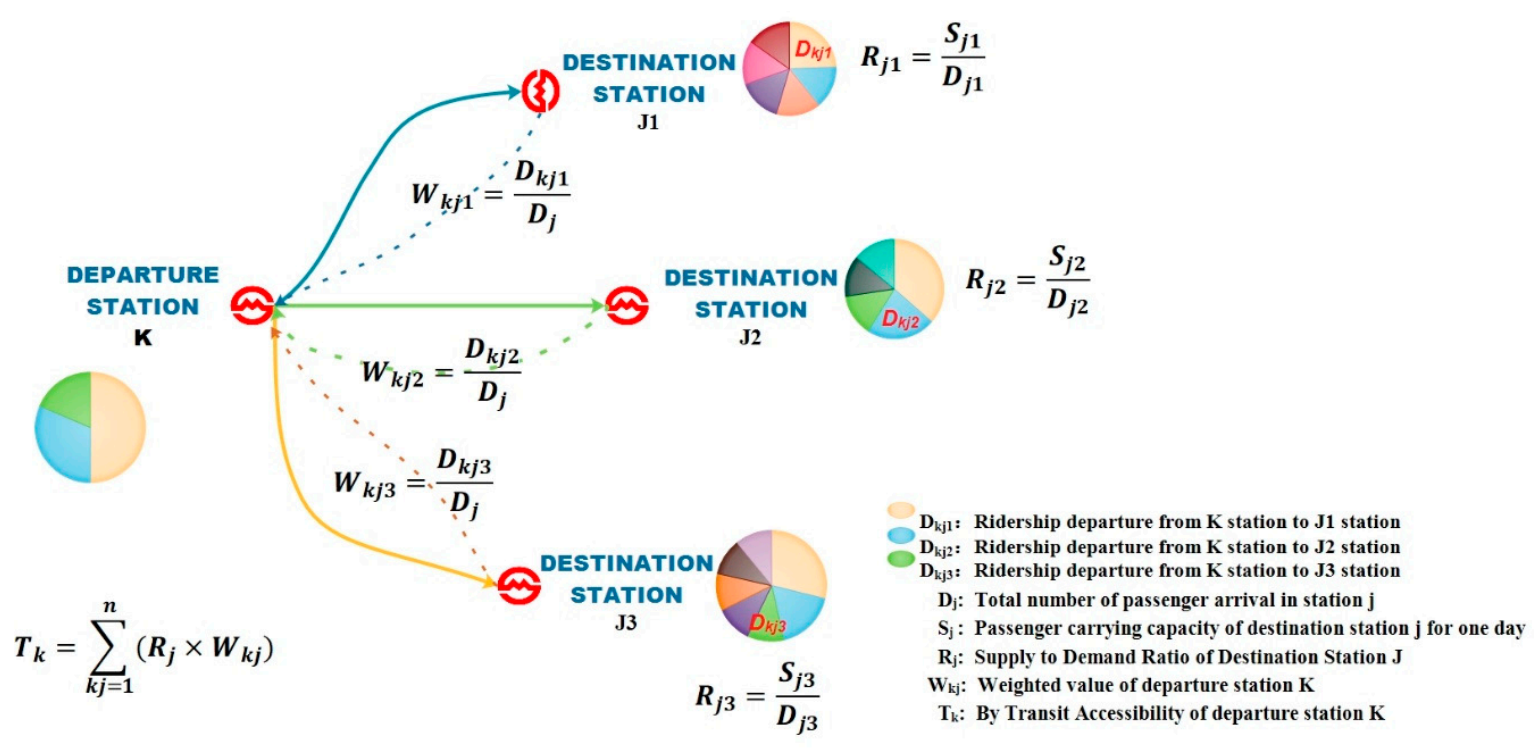

Figure 2. The method used to estimate the BTA at the departure station.

Distance decay can be calculated as the sum of the reciprocal of the distance from each TAZ to all the subway stations, though the negative exponential function is more suitable for small distance on the urban scale than the inverse power function [71]. So, we used the distance as the separation component and took the negative exponential function as the decay function.

Figure 3 shows the methodology framework for metrorail accessibility, and the full formula for metrorail accessibility in TAZ $i$ is

$$
\left.A_{i}=\sum_{k} T_{k} f\left(c_{i k}\right)=\sum_{k=1}^{n}\left(\frac{S_{j}}{D_{j}} \times W_{k j}\right) \times l_{i k}^{-2}\right)
$$

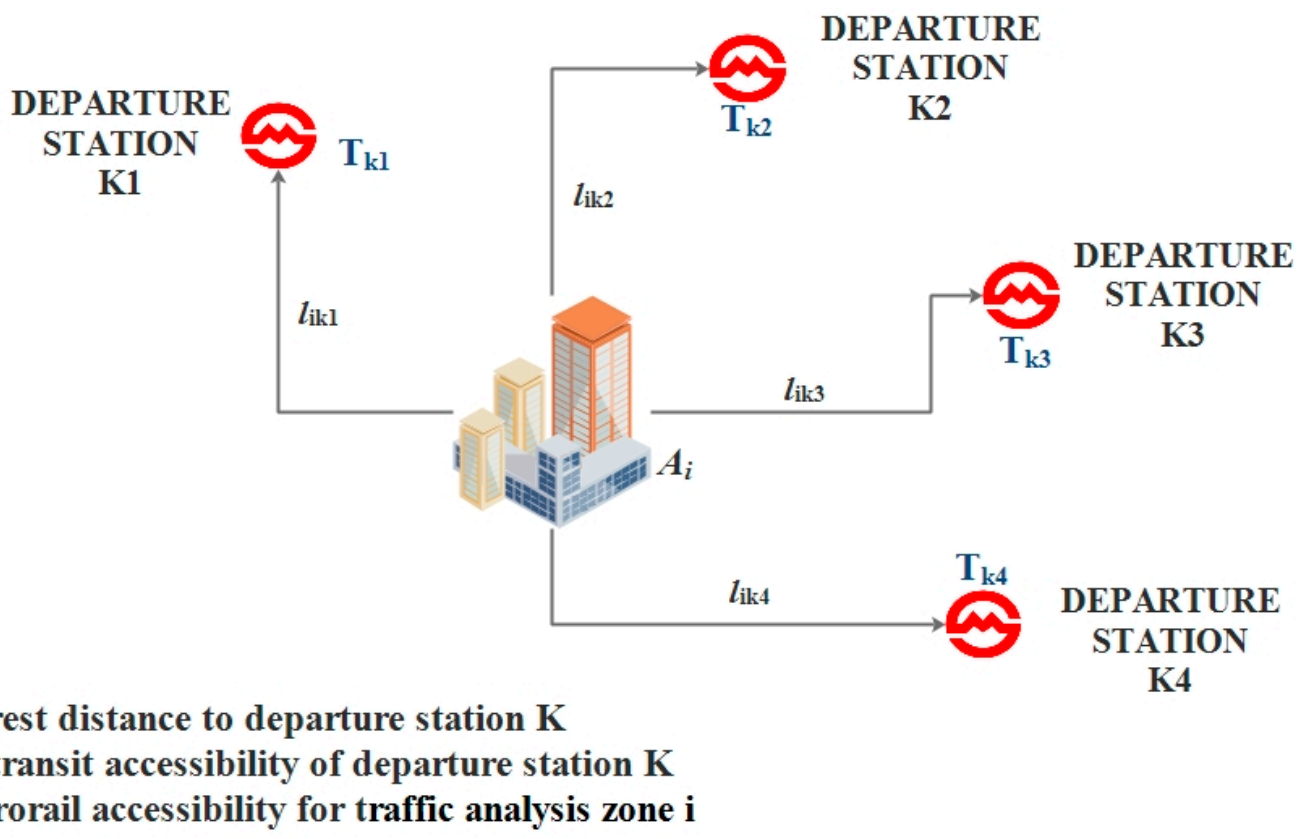

Figure 3. The methodology used to evaluate metrorail accessibility for each TAZ. 
Current research evaluates metrorail accessibility based on the distance-cost or timecost method within 15 minutes around a metro station from an objective perspective; however, this method has too many assumptions and the scope of analysis is limited to the station level [72]. The 3FCA model's reliability and robustness are better than the current model's assumptions, as the dataset for the 3SFCA model is based on actual passenger flow and demand for rail transit. Second, the model incorporates the distance or time limitation in the traditional model, and also includes the possibility of reaching all stations from the starting point. Finally, this model introduces the TAZ as the smallest research unit to evaluate the spatial balance of metrorail accessibility and to make recommendations for rail transit planning and TOD policy from different levels.

\subsection{Coordination Model}

\subsubsection{Data Standardization}

To avoid zero values and the extreme value, the MIN-MAX standardization method was adopted to standardize the value of FAR and Metro accessibility. The formula is as follows:

$$
Z_{i}=\frac{\left(X_{i}-X_{\min }\right)}{\left(X_{\max }-X_{\min }\right)}
$$

In the formula, $Z_{i}$ is the standardized value of the $i$ th-index, $X_{i}$ is the value of $i$ thindex, $X_{\max }$ is the maximum value of the $i$ th-index, and $X_{\min }$ is the minimum value of the ith-index.

\subsubsection{Coupling Degree Model}

Urban development is mainly divided into two modes of extension expansion and intensive development. In the process of extension expansion, the completeness of amenities stimulates urban growth, while the demand for public facilities gradually increases due to the intensive development [73]. In particular, the positive interaction between the development of public transportation and urban spatial form is clear [74].

The coupling degree is a physics concept [75], which refers to the phenomenon that two or more subsystems affect each other and transfer energy from one side to the other through various interactions [76]. In physics, this is a broad and common concept covering phenomena such as electro-thermal coupling, a fluid-structure, and inductive coupling, [77]. Social scientists used the physical concept of coupling and built the coupling measurement model by using the dispersion formula between multiple systems.

The degree of coupling was used to reflect the intensity of the interaction and influence in the systems [78]. The coupling degree model for the interaction between metrorail accessibility and urban spatial form can be calculated as follows:

$$
C\left(F A R_{i}, A_{i}\right)=2 \times \sqrt{\left(F A R_{i} \times A_{i}\right) /\left(F A R_{i}+A_{i}\right)^{2}} .
$$

In Equation (6), $C\left(F A R_{i}, A_{i}\right)$ is the coupling degree between urban spatial form and metrorail accessibility for parcel $i$, the value ranges from 0 to $1, F A R_{i}$ denotes the floor to area ratio for parcel $i, A_{i}$ denotes metrorail accessibility and both of the above indicators are dimensionless based on Equation (5).

\subsubsection{Coupling Coordination Development Model}

The Coordination index refers to the degree of coordination and influence between two or more attributes. In the process of urbanization, in order to realize a coordinated development of urbanization and transportation, we constructed a coordinated development model based on the metrorail accessibility and the index of urban spatial form. 
The coupling degree model is only a representation of the strength of the interaction between systems, and cannot effectively reflect the level of coordinated development [76]. To avoid this deficiency, the coordination degree model was introduced [78]:

$$
\begin{gathered}
H_{i}=\alpha F A R_{i}+\beta A_{i} \\
D_{i}=C\left(F A R_{i}, A_{i}\right) \times H_{i}
\end{gathered}
$$

In Equation (8), $D_{i}$ is the degree of coupling coordination for parcel $i ; H_{i}$ is the comprehensive development index of the two systems, obtained by the sum of equal weights of the two systems. It is believed that the importance of metrorail accessibility and urban spatial form are equally important. Therefore, we set the values of $\alpha$ and $\beta$ as 0.5 . In addition, in order to ensure comparability, we normalized two values, $F A R_{i}$ and $A_{i}$, by Equation (5), making $F A R_{i} \in(0,1)$, and then controlling $A_{i} \in(0,1)$.

\section{Results and Discussions}

\subsection{Urban Spatial Form}

The floor area ratio can, to some extent, reflect the spatial form of the city because the main elements of the city are different types of buildings. Also, the floor to land ratio is closely related to capital density because it is measured by the ratio of produced building area to the land use area. The lower the capital investment per unit of land, the lower the building density and floor area ratio [79]. Besides that, the floor-to-land ratio is closely related to urban population density and employment density. Since buildings serve humans, places with a high FAR will have a higher population density and employment density, and urban functions will be relatively efficient [80]. With the externalities of rail transit and the government's encouragement of a TOD policy approach, the population density and employment density around the stations are higher than in other areas far from the stations [81]. However, due to differences in geographic locations and construction costs, the construction density of station in a region will also differ. Therefore, to what extent does the location of a subway station have an effect on the development of the surrounding city will be the main questions explored in this section. We used a maximum distance of $2 \mathrm{~km}$ around the station to examine the spatial distribution of the urban form in Shanghai (Figure 4).

In general, the urban development pattern surrounding the Shanghai rail transit station represents a circle with a high central area and a low edge. This spatial pattern is found in many metropolises. In Shanghai, with the Huangpu River as a dividing line, the Puxi area is significantly denser than the Pudong area, owing to the good location advantage of the PuXi Area, high land value, high capital density, and agglomeration of various production departments, which reduces transportation costs. There are some sporadic stations with a high FAR value in the suburbs such as the Hongqiao Terminal and ShuYuan Station; these stations tend to be main intercity transport nodes or parts of the new CBD area. The average floor to area ratio (FAR) in Shanghai is 3.574, while the majority of FAR values are 3-5. The building with the highest floor is located near Shanghai Hongqiao Terminal and has a FAR of 26.125. FAR values greater than 10 are concentrated in the city center and along the west side of the Yangtze River. The Districts of Pudong and Fengx have a low FAR ratio in their suburbs.

To compare the urban spatial forms in different TAZs, we divided the TAZs within $2 \mathrm{~km}$ into five sections: $500 \mathrm{~m}, 800 \mathrm{~m}, 1000 \mathrm{~m}, 1500 \mathrm{~m}$, and $2000 \mathrm{~m}$ (Table 2). In general, the value of FAR decreases gradually from the city center to the suburbs and shows an inverted U-shaped curve that increases first and then decreases for the TAZs located further away from each station. The area with the highest FAR value from the first to the third ring is concentrated between $800 \mathrm{~m}$ and $1000 \mathrm{~m}$, while the FAR value of the fourth ring area is concentrated between $500 \mathrm{~m}$ and $800 \mathrm{~m}$. 


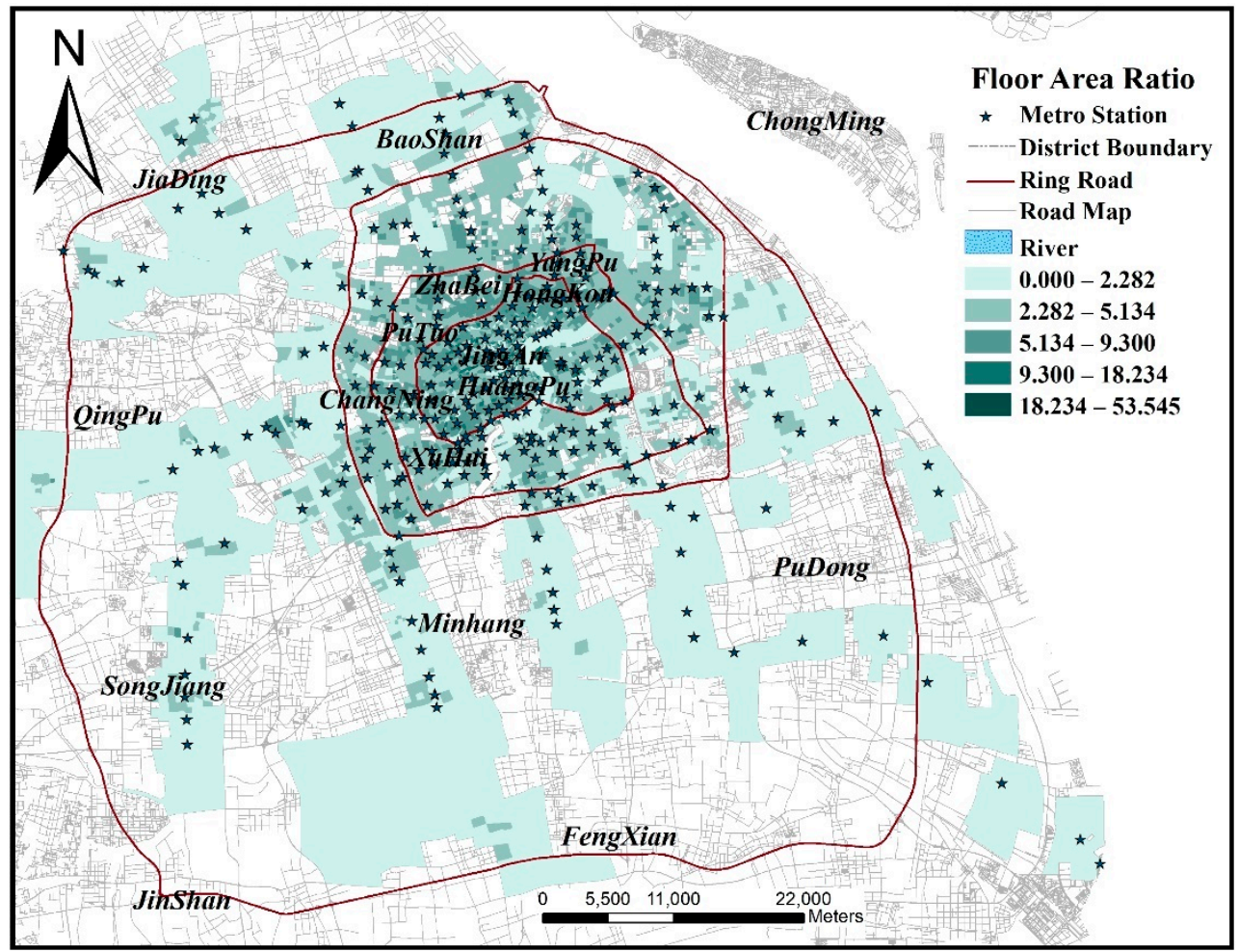

Figure 4. Urban Spatial Form within the catchment area of stations.

Table 2. Average Floor Area Ratio in various service areas and rings.

\begin{tabular}{cccccc}
\hline Average Density & First Ring & $\begin{array}{c}\text { Second } \\
\text { Ring }\end{array}$ & Third Ring & Fourth Ring & Total \\
\hline $500 \mathrm{~m}$ & 4.9139 & 3.6984 & 2.6620 & 2.0209 & 4.0601 \\
$800 \mathrm{~m}$ & 5.5402 & 4.2620 & 3.4625 & 2.4513 & 4.5140 \\
$1000 \mathrm{~m}$ & 7.1026 & 5.1184 & 4.2177 & 2.4140 & 3.9509 \\
$1500 \mathrm{~m}$ & 5.1725 & 4.0148 & 3.4159 & 1.9911 & 3.4713 \\
$2000 \mathrm{~m}$ & 3.3991 & 3.8013 & 3.5071 & 1.8967 & 2.4030 \\
Total & 4.5629 & 3.9311 & 3.5103 & 2.0421 & 3.8035 \\
\hline
\end{tabular}

There are four reasons for the differences between regions and stations. One reason is that different land use types have different traffic requirements. Commercial land is primarily concentrated in the station area, which has a high passenger flow, so it is preferable for this land to be closer to the station. Residential land has relatively low location requirements and is generally distributed around commercial areas. Second, the positive externalities of public transportation, such as convenience, attract a large number of real estate departments to locate there, but there are also negative externalities such as noise, pollution, and traffic volumes surrounding public transportation; thus, the urban form around urban rail transit shows inverted U-shaped distribution characteristics.

Third, the slope of the commercial land price curve in the city center is steeper, and the height of commercial buildings is lower than that of residential land, so areas with higher FAR values are further away from the station than in the suburban area. Finally, due to the earlier development of the city center area and the longer time for building replacement, the building floors in the city center area are higher, while the value of these floors is lower in suburban areas.

\subsection{Metrorail Accessibility}

Metrorail accessibility not only includes the value of 'by transit accessibility', but also contains the value of 'to transit accessibility'. Based on different distance thresholds, we 
calculated the opportunities for people to reach railway stations, which showed a strong positive relationship to the thresholds. This chapter analyzes the spatial distribution of accessibility through transit and metrorail accessibility separately.

\subsubsection{By Transit Accessibility}

The map 'By transit accessibility' is shown in Figure 5. Overall, this value shows a pattern of slowly decreasing from the inside to the outside, suggesting that the town center has higher accessibility, while the suburban accessibility is lower. The most popular accessibility stations are the People's Square, Shanghai Rail Station, Xujiahui, Nanjing East Road, and other areas close to the commercial or transport center. Many of them are situated on the ring road along the Yangtze River. In addition, large interchange stations primarily have high-accessibility values.

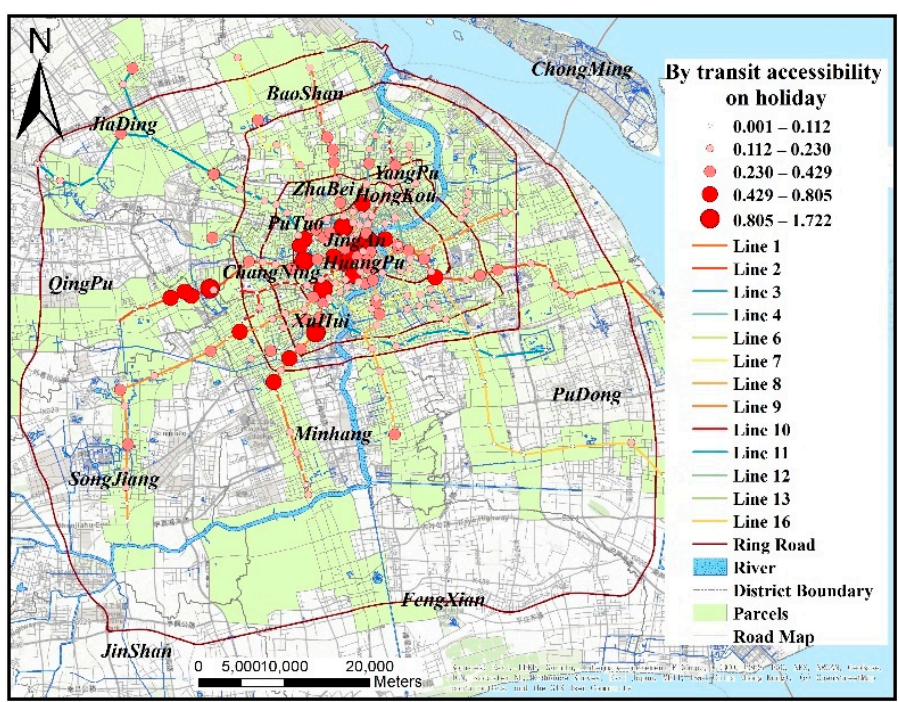

(a) Holiday

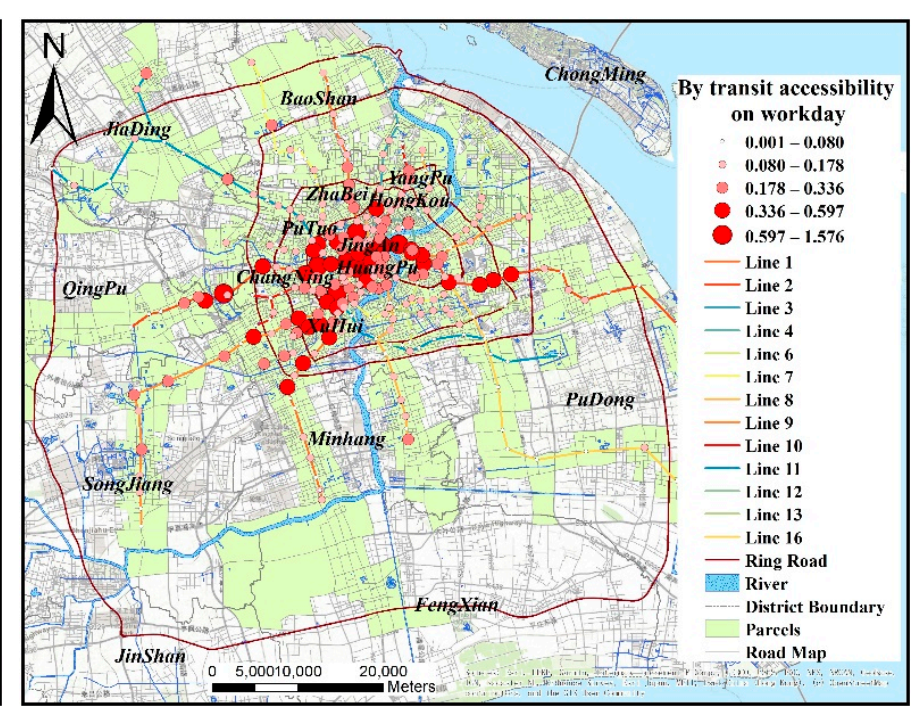

(b) Workday

Figure 5. Distribution of transit accessibility by station.

Based on the results, the accessibility of transmission stations is 3.75 times that of non-transfer stations and the average accessibility for each additional line is 150 percent higher. Lines 2 and 1 are considered to have the highest average accessibility, i.e., 0.5315 and 0.3578 , primarily because lines 2 and 1 began operations in 2000 and 1993, each with a longer operating time and most stations are located in the center urban area, so the scope of service is has a higher density than in other areas.

Lines 16 and 6 have the worst average accessibility, as their main service areas are suburban areas like Nanhui New City and Pudong New Area, and the construction period for these lines was shorter. However, there are still some highly accessible stations in the city suburbs, such as NanXiang and the Pengpu county station. This is mainly because of the densely populated areas located in Pudong and the Baoshan District. The total population in the district of Baoshan is 2.0308 million and the resident population of the new district of Pudong is 5.5284 million, which is a gathering area for migrant workers.

The average accessibility value for workdays is 0.168 , the standard deviation is 0.198 , while the average accessibility value for holidays is 0.185 , and the standard deviation is 0.212 . The spatial distribution of more accessible sites is also more dispersed on holidays. For instance, the suburb stations Songiiang University City and Shanghai Circuit station are much more widely used on holidays compared to working days. The difference in BTA between working days and holidays is primarily due to differences in the spatial distribution of urban functions. The increase in passenger flows from the station hub areas and university towns during the holidays contributes significantly to the improvement in BTA in suburban areas. On workdays, the concentration of accessibility in the urban center 
area is primarily due to the area's proximity to the core business service area and office area, which appears to be increasing accessibility during workdays.

\subsubsection{Metrorail Accessibility}

The spatial distribution of rail transit accessibility values appears as a concentric circle distribution, which is consistent with the Shanghai rail transit loop. From Figure 6, the service capabilities of rail transit in different regions show obvious spatial heterogeneity. The majority of the first, second, and third rings are within the 2000-m rail transit service radius, while only half of the fourth ring is within the rail transit service radius. Furthermore, the spatial difference in rail transit accessibility values between regions is much greater than that between stations, indicating that the development of rail transit in Shanghai is primarily influenced by geographical factors, and the density of rail transit stations corresponds to the city's development stages. As a result, the distribution of metrorail accessibility reflects regional heterogeneity while remaining relatively consistent between stations.

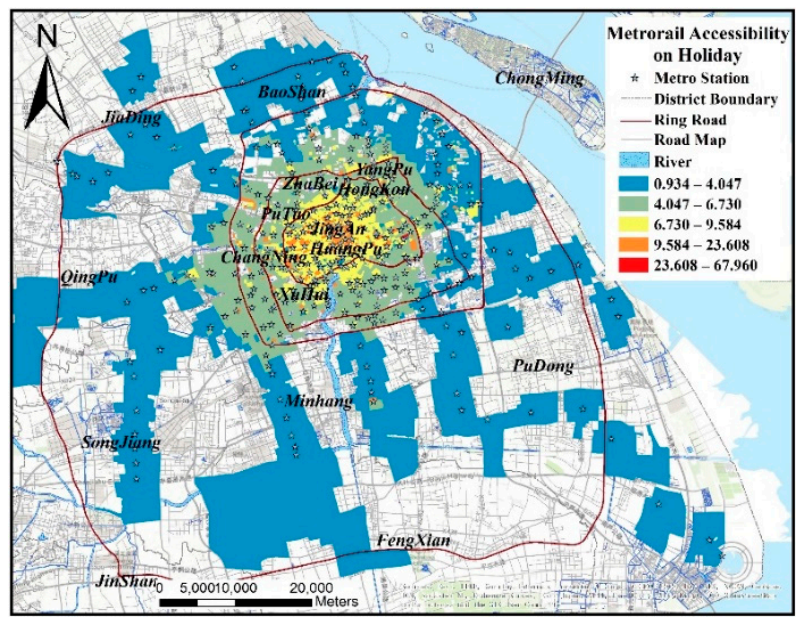

(a) Holiday

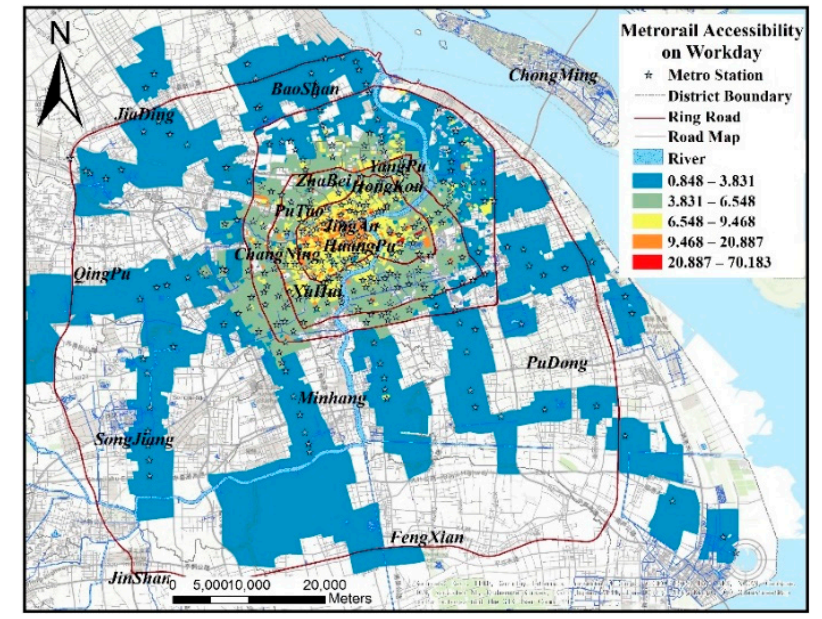

(b) Workday

Figure 6. Distribution of metrorail accessibility by the station.

The accessibility value of the first ring of the city center is the highest among regions based on the spatial distribution of the starting point (TAZs), and the accessibility of the station near the Bund is higher than for other parcels. Shanghai's rail accessibility primarily reflects the distribution trend of a ring-shaped development with a high southwest and low northwest. Outside of the third ring road, station accessibility is relatively low, with the exception of the large public transportation hub area.

Table 3 shows that the accessibility of rail transit around Shanghai's central urban site experienced a slow decline followed by a rapid decline. The accessibility between 800 and $1000 \mathrm{~m}$ has significantly decreased. According to the core-periphery theory [82], the city's main functional area, as the city's population resource gathering place, has a high demand for public transportation, and the early stages of subway station construction are primarily determined by population density and demand.

The areas where rail transit stations have the greatest impact are mainly focused in the second and third ring roads. The distance threshold for rail transit accessibility within the second ring is $1000-1500 \mathrm{~m}$, and the distance threshold within the third ring is $1500-2000 \mathrm{~m}$. Because the second and third ring roads are located in the upper transition area, they have a certain economic connection with the downtown area; for this transition area, the population density is increasing while the daily commuting demand is gradually increasing, and it is highly dependent on rail transit. Outside of the city center, the difference in accessibility is relatively small; the highest value is in the $500-800 \mathrm{~m}$ interval, primarily because this area is within walking distance of rail transit, which allows people 
to not only benefit from the positive externalities of rail transit, but also avoid the noise and pollution caused by large crowds.

Furthermore, during holidays, the outer ring's rail transit accessibility is higher than on weekdays, while the inner ring's accessibility value is lower, owing to the fact that the central city is a working cluster area, whereas the core function of the outer ring city is business and leisure districts. This shows that the attractiveness of working days and holidays is affected differently by different urban functions.

Table 3. Average accessibility of metrorail in various service areas and rings.

\begin{tabular}{ccccccc}
\hline Types & Distance Threshold & First Ring & Second Ring & Third Ring & Fourth Ring & Total \\
\hline & $500 \mathrm{~m}$ & 8.4852 & 5.8625 & 4.4607 & 2.7529 & 5.9816 \\
Average & $800 \mathrm{~m}$ & 8.3847 & 5.8349 & 4.6141 & 2.9553 & 6.3719 \\
Workday & $1000 \mathrm{~m}$ & 7.9968 & 5.8556 & 4.5611 & 2.9231 & 5.7024 \\
Accessibility & $1500 \mathrm{~m}$ & 7.6818 & 5.6610 & 4.4242 & 2.8126 & 4.9297 \\
& $2000 \mathrm{~m}$ & 6.1111 & 4.9222 & 4.0945 & 2.7119 & 3.4785 \\
& Total & 8.1954 & 5.7276 & 4.4414 & 2.8128 & 5.4606 \\
\hline & $500 \mathrm{~m}$ & 8.4708 & 5.9996 & 4.6942 & 3.0709 & 6.1108 \\
Average & $800 \mathrm{~m}$ & 8.3777 & 5.9797 & 4.8368 & 3.2923 & 6.4867 \\
Holiday & $1000 \mathrm{~m}$ & 7.9621 & 5.9943 & 4.7771 & 3.2472 & 5.8358 \\
Accessibility & $1500 \mathrm{~m}$ & 7.6498 & 5.8186 & 4.6372 & 3.1079 & 5.1021 \\
& $2000 \mathrm{~m}$ & 6.2122 & 5.1106 & 4.3221 & 2.9826 & 3.7168 \\
\hline
\end{tabular}

\subsection{Spatial Coordination between Metrorail Accessibility and Urban Spatial Form}

The level of spatial coordination between rail transit and urban spatial structure reflects the degree of balance between rail transit and urban spatial development. As illustrated in Figure 7, the degree of spatial coupling between the two demonstrates significant regional heterogeneity. The further away you are from the central business district, the less spatial coupling there is between the two. In urban business districts, the urban spatial development form and urban functions are relatively complete, whereas in the city's periphery, the degree of matching between accessibility and the urban spatial form is lower.

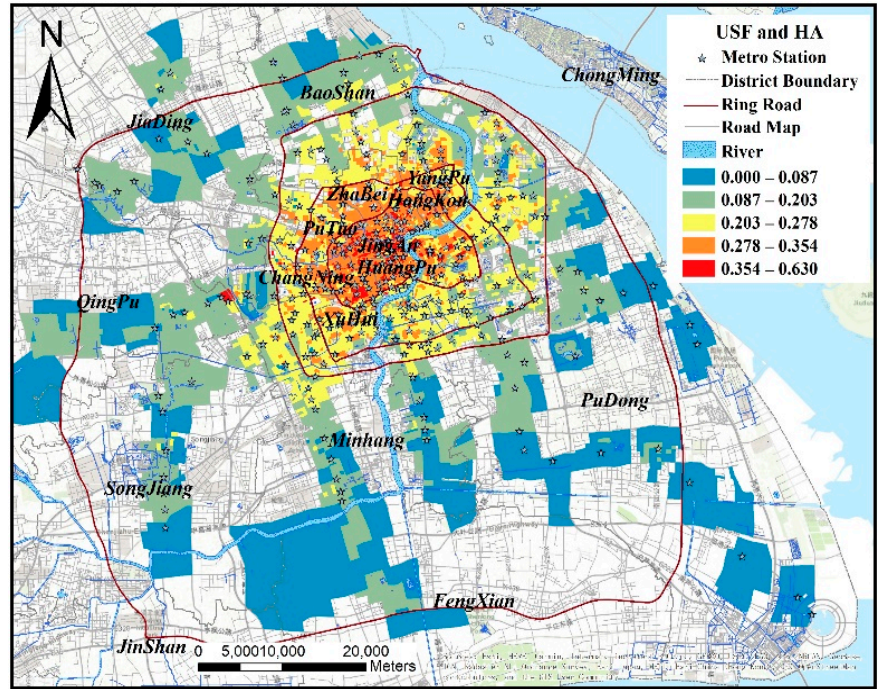

(a) Metrorail accessibility and USF during holidays

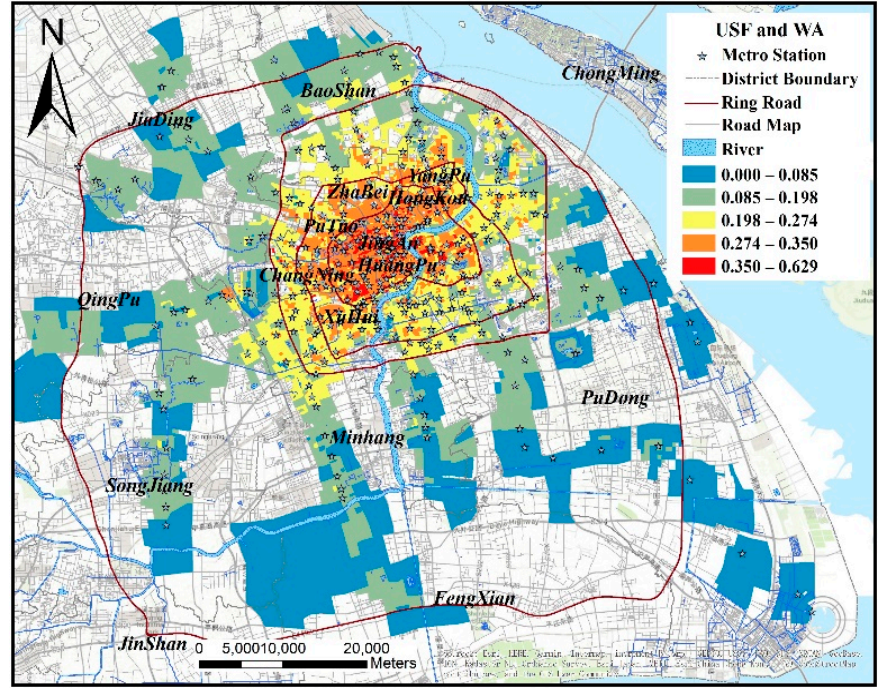

(b) Metrorail accessibility and USF during workdays

Figure 7. Spatial Coordination between metrorail accessibility and urban spatial form.

In urban business districts, the urban spatial development form and urban functions are relatively complete, while the matching degree between the accessibility and urban 
spatial form are lower in the periphery of the city. The urban business district, due to its geographical location advantages, not only has higher accessibility, but also has the advantage of an agglomeration economy, so the coordination between urban accessibility and FAR value is relatively high. For the periphery areas, though the urban rail transit construction plan is in progress, the overall coupling of the periphery is low due to the time required to complete the plan's industrial and urban functions.

The degree of spatial coupling between rail transit accessibility and urban morphology is stronger at the regional level but weaker at the station level. The main reason for this is that the rail transit accessibility for various communities at the station level is relatively high within one kilometer, while it shows a significant downward trend beyond one kilometer. Additionally, both the FAR and accessibility show decreases beyond $1 \mathrm{~km}$. Overall, the difference in the degree of coupling between the two on holidays and working days is not obvious. The areas that have obvious changes are Shanghai Hongqiao Airport, Shanghai South Railway Station, and other transportation hub areas, primarily because the rail transit demand at the above stations has increased significantly during holidays and the accessibility has also increased significantly.

We can find the following characteristics in Table 4: (1) Compared to weekdays, metrorail transit accessibility of the second and third ring roads during holidays has improved, while accessibility to other areas remains lower. This is primarily due to the increase in activities near shopping malls along the second and third ring roads during the holidays, as well as the improved accessibility of suburban stations; (2) The spatial coupling between the city and the suburbs gradually declines from the central city to the suburbs, owing to the sequence of rail transit construction between the city and the suburbs. Land development in the central city existed prior to the construction of urban rail transit, and rail station locations are primarily determined by passenger flow demand and construction costs [83]. In contrast, rail transit planning drives the development of urban spatial layout in urban suburbs. As a result, urban rail transit construction comes first, followed by land development and construction. However, there is a time lag between the two in the suburbs due to the time lag of the spillover benefits of urban rail transit. Thus, the level of coordination degree remains low between urban and suburban areas; (3) In terms of service radius, the area between 500 and $800 \mathrm{~m}$ in the central urban area has the highest degree of coordination. In the second ring road area, the highest coordination degree area is mainly concentrated at about $800 \mathrm{~m}$ to $1000 \mathrm{~m}$. The coordination degree with a higher degree is approximately $500-1000 \mathrm{~m}$ in the third ring road area and approximately $800-1000 \mathrm{~m}$ in the fourth ring road area. To summarize, the area with the highest coupling degree on both sides in the first ring area is concentrated in the range of 500-800 m, while the coupling degree of the other areas is primarily concentrated in the range of 800-1000 m. By comparing Tables 2 and 3 , the results show that the decrease in the coordination degree is primarily due to the low floor to area ratio in the suburban regions.

The purpose of this paper was to calculate the value of metrorail accessibility in the catchment area of Shanghai stations from the perspective of passenger behavior. In comparison to current research, the method adopted in this paper uses a large amount of data and is able to generate relatively robust calculation results, but it requires a high-quality and large amount of dataset. We analyzed the relationship between metrorail accessibility and urban form using the coupled coordinate model, which is well suited to reflect the spatial local relationship between the two. However, due to the large scope of accessibility spillover effects on land use and the agglomeration effect of urban rail development and urban planning, the spatial coupling coordinate model could not reflect the relationship between accessibility and land use near the local area. This study evaluates the accessibility of metrorail within $2 \mathrm{~km}$ from a station, which has some guiding significance for the implementation of TOD policies, though the assessment of the accessibility value over $2 \mathrm{~km}$ could not be estimated. In future research, it would be necessary to strengthen the research about the spatial spillover effect of metrorail accessibility on land use from a 
global perspective, in order to provide guidance on the overall development of Shanghai's urban planning.

Table 4. Average degree of spatial coordination in various service areas and rings.

\begin{tabular}{ccccccc}
\hline Types & Distance ThreshOld & First Ring & Second Ring & Third Ring & Fourth Ring & Total \\
\hline Average & $500 \mathrm{~m}$ & 0.3082 & 0.2517 & 0.2228 & 0.1246 & 0.2426 \\
Workday & $800 \mathrm{~m}$ & 0.3092 & 0.2521 & 0.2301 & 0.1402 & 0.2587 \\
Accessibility & $1000 \mathrm{~m}$ & 0.3040 & 0.2530 & 0.2300 & 0.1409 & 0.2433 \\
and Urban & $1500 \mathrm{~m}$ & 0.2979 & 0.2491 & 0.2293 & 0.1369 & 0.2225 \\
Spatial Form & $2000 \mathrm{~m}$ & 0.2591 & 0.2346 & 0.2198 & 0.1314 & 0.1740 \\
& Total & 0.3056 & 0.2501 & 0.2269 & 0.1346 & 0.2334 \\
\hline Average & $500 \mathrm{~m}$ & 0.3102 & 0.2550 & 0.2274 & 0.1292 & 0.2459 \\
Holiday & $800 \mathrm{~m}$ & 0.3113 & 0.2554 & 0.2345 & 0.1454 & 0.2619 \\
Accessibility & $1000 \mathrm{~m}$ & 0.3060 & 0.2562 & 0.2343 & 0.1460 & 0.2467 \\
and Urban & $1500 \mathrm{~m}$ & 0.3000 & 0.2524 & 0.2336 & 0.1417 & 0.2262 \\
Spatial Form & $2000 \mathrm{~m}$ & 0.2618 & 0.2381 & 0.2243 & 0.1359 & 0.1783 \\
& Total & 0.3076 & 0.2534 & 0.2313 & 0.1393 & 0.2369 \\
\hline
\end{tabular}

\section{Conclusions}

In China, integrated transportation and urban spatial forms play a critical role, as rapid growth shifts create new opportunities for connecting transportation and urban developments, such as transit-oriented development (TOD) and urban regeneration programs. The traditional accessibility model measures public service accessibility using a time or distance threshold. However, it ignores the physical needs of the individual. This article first updated metrorail accessibility by combining the TTA and BTA from the perspective of actual travel demand, then calculated urban spatial form using the floor area ratio, and finally examined the degree of coordination between metrorail accessibility and urban spatial form. The main findings are:

Shanghai's urban development is characterized by a monocentric spatial structure. The FAR value decreases gradually from the central area to the suburbs, and the floor area ratio east and west of the Huangpu River is obviously different. From the station's perspective, the distance to the station at the highest FAR value varies by region. The highest FAR value is located between 800 and $1000 \mathrm{~m}$ from the station on the third ring road, while the highest FAR value is located between 500 and $800 \mathrm{~m}$ in the suburbs.

In terms of TTA, the values are higher in areas where the line has operated for a longer period of time, that are densely populated, or that are located in urban centers. As rail transit development has a time lag effect, the construction of rail transit in central urban areas is determined by passenger flow demand, whereas the construction of suburban stations is determined by urban planning. Planning policies are still being implemented in the second and third ring areas. However, accessibility around the fourth ring road stations, particularly in the Pudong area, remains limited. As a result, the introduction of industries and talents in the Pudong area should be enhanced in order to increase the passenger flows at the area's stations.

The spatial distribution trend of rail transit accessibility is consistent with the urban construction density. From the inner ring to the outer ring, the catchment area of rail transit accessibility shows the characteristics of gradually expanding and then shrinking, while the areas most affected by rail transit are in the second and third ring roads. Because of relatively mature development of the rail transit in this area and the completion of commercial service facilities, these areas have the metrorail transit largest catchment area, as compared to the more congested inner ring area and the incomplete public facilities in the outer ring area.

As presented in Figure 7, there is a strong correlation between rail transit accessibility and urban development in the majority of areas surrounding metro stations. The degree of spatial coordination between the two can not only be used to analyze the spatial balance 
between rail transit and urban construction from a supply and demand perspective, but can also provide reference suggestions for the next location of the TOD program. From the inner ring area to the outer ring area, the degree of coupling between the two decreases gradually, but the service range of the stations exhibits an inverted U-shaped regional distribution, owing to the low station construction density in the outer ring area, the late planning and construction year for rail transit, as well as the reduced job opportunities in the outer ring area.

As a result, we should implement different policy recommendations for rail transit development in accordance with the development characteristics of various regions. For example, in Shanghai's suburban area, a reference range of $800 \mathrm{~m}$ can be considered to increase station density in the fourth ring area, which should improve urban development and attract industries to areas surrounding the stations. In the area of the second and third ring roads, we should consider increasing the density of land use within $1000 \mathrm{~m}$ of stations and establishing TOD stations or comprehensive service centers in areas with high passenger volumes, such as the Xuhui and Changning districts. In the urban center area, the carrying capacity of rail transit should be increased to meet future rail transit demand, and the transportation network connecting Pudong and Puxi should be strengthened to promote rail transit and industry development in Puxi. Meanwhile, to avoid wasting a lot of land resources, we need to adjust land use planning around metrorail stations based on travel demand in different regions. These specific recommendations will serve as a valuable guide for developing integrated land-transportation projects for different stations in various regions.

Author Contributions: Conceptualization, J.L.; methodology, J.L.; software, J.L.; validation, J.L.; resources, X.H. and C.X.; data curation, X.K. and Y.Z.; writing-original draft preparation, J.L.; writing - review and editing, X.H. and J.L. All authors have read and agreed to the published version of the manuscript.

Funding: This work was funded by the Thesis Scholarship of Peking University-Lincoln Research Center for urban development and land policy (Grant No. DS03-20201001-LJM), the MOE (Ministry of Education of China) Humanities, Social Sciences Fund (Grant No. 18YJCZH049), the National Natural Science Foundation of China (Grant No. 71873098 and 42071416), the China Postdoctoral Science Foundation (Grant No. 2018M633596), and the Natural Science Basic Research Plan in Shaanxi Province of China (Grant No. 2018JQ7005).

Institutional Review Board Statement: Not applicable.

Informed Consent Statement: Informed consent was obtained from all subjects involved in the study. Written informed consent has been obtained from the patient(s) to publish this paper.

Data Availability Statement: Data are available via the Shanghai Public Data Open Platform ( data.sh.gov.cn//index.html, Year: 2018).

Conflicts of Interest: The authors declare no conflict of interest.

$\begin{array}{ll}\text { Abbreviation } \\ \text { TTA } & \text { To Transit Accessibility } \\ \text { BTA } & \text { By Transit Accessibility } \\ \text { USF } & \text { Urban Spatial Form } \\ \text { FAR } & \text { Floor area ratio } \\ \text { 2SFCA } & \text { The two-step floating catchment area } \\ \text { 3SFCA } & \text { The three-step floating catchment area }\end{array}$

\section{References}

1. Bertolini, L. Spatial Development Patterns and Public Transport: The Application of an Analytical Model in the Netherlands. Plan. Pr. Res. 1999, 14, 199-210. [CrossRef]

2. Suzuki, H.; Cervero, R.; Iuchi, K. Transforming Cities with Transit: Transit and Land-Use Integration for Sustainable Urban Development; World Bank Publications: Washington, DC, USA, 2013. 
3. Qu, Y.; Zhou, X. Large-Scale Dynamic Transportation Network Simulation: A Space-Time-Event Parallel Computing Approach. Transp. Res. Part C Emerg. Technol. 2017, 75, 1-16. [CrossRef]

4. Sakamoto, K.; Iida, A.; Yokohari, M. Spatial Patterns of Population Turnover in a Japanese Regional City for Urban Regeneration against Population Decline: Is Compact City Policy Effective? Cities 2018, 81, 230-241. [CrossRef]

5. Falcocchio, J.C.; Levinson, H.S. Road Traffic Congestion: A Concise Guide; Springer: Cham, Switzerland, 2015 ; Volume 7.

6. Pan, T.; Lam, W.H.K.; Sumalee, A.; Zhong, R. Multiclass Multilane Model for Freeway Traffic Mixed with Connected Automated Vehicles and Regular Human-Piloted Vehicles. Transp. Transp. Sci. 2021, 17, 5-33. [CrossRef]

7. Madireddy, M.; De Coensel, B.; Can, A.; Degraeuwe, B.; Beusen, B.; De Vlieger, I.; Botteldooren, D. Assessment of the Impact of Speed Limit Reduction and Traffic Signal Coordination on Vehicle Emissions Using an Integrated Approach. Transp. Res. D Transp. Environ. 2011, 16, 504-508. [CrossRef]

8. Salazar, E.; Henríquez, C.; Durán, G.; Qüense, J.; Puente-Sotomayor, F. How to Define a New Metropolitan Area? The Case of Quito, Ecuador, and Contributions for Urban Planning. Land (Basel) 2021, 10, 413.

9. Grengs, J. Job Accessibility and the Modal Mismatch in Detroit. J. Transp. Geogr. 2010, 18, 42-54. [CrossRef]

10. Levine, J.; Grengs, J.; Shen, Q.; Shen, Q. Does Accessibility Require Density or Speed? A Comparison of Fast versus Close in Getting Where You Want to Go in US Metropolitan Regions. J. Am. Plan. Assoc. 2012, 78, 157-172. [CrossRef]

11. Martens, K. Accessibility and Potential Mobility as a Guide for Policy Action. Transp. Res. Rec. 2015, 2499, 18-24. [CrossRef]

12. Cheng, J.; Bertolini, L.; Clercq, F.; Kapoen, L. Understanding Urban Networks: Comparing a Node-, a Density-and an AccessibilityBased View. Cities 2013, 31, 165-176. [CrossRef]

13. Miller, H.J. Place-Based versus People-Based Accessibility. In Access to Destinations; Levinson, D., Krizek, K.J., Eds.; Emerald Group Publishing Limited: Bingley, UK, 2005; pp. 63-89.

14. Geurs, K.T.; van Wee, B. Accessibility Evaluation of Land-Use and Transport Strategies: Review and Research Directions. J. Transp. Geogr. 2004, 12, 127-140. [CrossRef]

15. Clifton, N. The "Creative Class" in the Uk: An Initial Analysis. Geogr. Ann. Ser. B 2008, 90, 63-82. [CrossRef]

16. Feng, J.; Dijst, M.; Prillwitz, J.; Wissink, B. Travel Time and Distance in International Perspective: A Comparison between Nanjing (China) and the Randstad (The Netherlands). Urban Stud. 2013, 50, 2993-3010. [CrossRef]

17. Levine, J.; Grengs, J.; Merlin, L.A. From Mobility to Accessibility: Transforming Urban Transportation and Land-Use Planning; Cornell University Press: Ithaca, NY, USA, 2019.

18. Dittmar, H.; Ohland, G. (Eds.) The New Transit Town: Best Practices in Transit-Oriented Development; Island Press: Washington, DC, USA, 2004.

19. Cervero, R.; Murakami, J. Rail and Property Development in Hong Kong: Experiences and Extensions. Urban Stud. 2009, 46, 2019-2043. [CrossRef]

20. Wang, X.; Tong, D.; Gao, J.; Chen, Y. The Reshaping of Land Development Density through Rail Transit: The Stories of Central Areas vs. Suburbs in Shenzhen, China. Cities 2019, 89, 35-45. [CrossRef]

21. Yu, M.; Fan, W. Accessibility Impact of Future High Speed Rail Corridor on the Piedmont Atlantic Megaregion. J. Transp. Geogr. 2018, 73, 1-12. [CrossRef]

22. Zuo, T.; Wei, H.; Chen, N.; Zhang, C. First-and-Last Mile Solution via Bicycling to Improving Transit Accessibility and Advancing Transportation Equity. Cities 2020, 99, 102614. [CrossRef]

23. Engelfriet, L.; Koomen, E. The Impact of Urban Form on Commuting in Large Chinese Cities. Transportation (Amst.) 2018, 45, 1269-1295. [CrossRef]

24. Kumar, P.P.; Sekhar, C.R.; Parida, M. Residential Dissonance in TOD Neighborhoods. J. Transp. Geogr. 2018, 72, 166-177. [CrossRef]

25. Steele, W.; Hussey, K.; Dovers, S. What's Critical about Critical Infrastructure? Urban Policy Res. 2017, 35, 74-86. [CrossRef]

26. Luo, W.; Qi, Y. An Enhanced Two-Step Floating Catchment Area (E2SFCA) Method for Measuring Spatial Accessibility to Primary Care Physicians. Health Place 2009, 15, 1100-1107. [CrossRef]

27. Xu, W.; Li, Y.; Wang, H. Transit Accessibility for Commuters Considering the Demand Elasticities of Distance and Transfer. J. Transp. Geogr. 2016, 56, 138-156. [CrossRef]

28. Welch, T.F.; Mishra, S. A Measure of Equity for Public Transit Connectivity. J. Transp. Geogr. 2013, 33, 29-41. [CrossRef]

29. Fransen, K.; Neutens, T.; Farber, S.; De Maeyer, P.; Deruyter, G.; Witlox, F. Identifying Public Transport Gaps Using TimeDependent Accessibility Levels. J. Transp. Geogr. 2015, 48, 176-187. [CrossRef]

30. Tong, L.; Zhou, X.; Miller, H.J. Transportation Network Design for Maximizing Space-Time Accessibility. Trans. Res. Part B Methodol. 2015, 81, 555-576. [CrossRef]

31. Tuzun Aksu, D.; Ozdamar, L. A Mathematical Model for Post-Disaster Road Restoration: Enabling Accessibility and Evacuation. Transp. Res. Part E Logist. Trans. Rev. 2014, 61, 56-67. [CrossRef]

32. Wang, G.; Zhong, Y.; Teo, C.-P.; Liu, Q. Flow-Based Accessibility Measurement: The Place Rank Approach. Transp. Res. Part C Emerg. Technol. 2015, 56, 335-345. [CrossRef]

33. Yang, S.; Liu, X.; Wu, Y.J.; Woolschlager, J.; Coffin, S.L. Can Freeway Traffic Volume Information Facilitate Urban Accessibility Assessment? Case Study of the City of St. Louis. J. Transp. Geogr. 2015, 44, 65-75. [CrossRef]

34. Hansen, W.G. How Accessibility Shapes Land Use. J. Am. Inst. Plan. 1959, 25, 73-76. [CrossRef]

35. Wang, F.; Tang, Q. Planning toward Equal Accessibility to Services: A Quadratic Programming Approach. Environ. Plan. B Plan. Des. 2013, 40, 195-212. [CrossRef] 
36. Curl, A.; Nelson, J.D.; Anable, J. Same Question, Different Answer: A Comparison of GIS-Based Journey Time Accessibility with Self-Reported Measures from the National Travel Survey in England. Comput. Environ. Urban Syst. 2015, 49, 86-97. [CrossRef]

37. Mavoa, S.; Witten, K.; McCreanor, T.; O'Sullivan, D. GIS Based Destination Accessibility via Public Transit and Walking in Auckland, New Zealand. J. Transp. Geogr. 2012, 20, 15-22. [CrossRef]

38. Whitehead, J.C.; Dumas, C.F.; Herstine, J.; Hill, J.; Buerger, B. Valuing Beach Access and Width with Revealed and Stated Preference Data. Mar. Resour. Econ. 2008, 23, 119-135. [CrossRef]

39. Leitham, S.; McQuaid, R.W.; Nelson, J.D. The Influence of Transport on Industrial Location Choice: A Stated Preference Experiment. Transp. Res. Part A Policy Pract. 2000, 34, 515-535. [CrossRef]

40. Marcucci, E.; Gatta, V. Regional Airport Choice: Consumer Behaviour and Policy Implications. J. Transp. Geogr. 2011, 19, 70-84. [CrossRef]

41. Cascetta, E.; Cartenì, A.; Montanino, M. A New Measure of Accessibility Based on Perceived Opportunities. Procedia Soc. Behav. Sci. 2013, 87, 117-132. [CrossRef]

42. Witter, R. Public Urban Transport, Travel Behavior and Social Exclusion-the Case of Santiago de Chile; XII World Conference on Transportation Research: Lisbon, Portugal, 2010.

43. Mamun, S.A.; Lownes, N.E.; Osleeb, J.P.; Bertolaccini, K. A Method to Define Public Transit Opportunity Space. J. Transp. Geogr. 2013, 28, 144-154. [CrossRef]

44. Moniruzzaman, M.; Páez, A. Accessibility to Transit, by Transit, and Mode Share: Application of a Logistic Model with Spatial Filters. J. Transp. Geogr. 2012, 24, 198-205. [CrossRef]

45. Shadabmehr, H.; Rahnama, M.R.; Ajza Shokoh, M.; Mafi, E.A. Reforming the Main Public Transport Systems Path of Mashhad City Using Ant Colony Algorithm and Improving Access. Geogr. Plan. Space 2019, 9, 1-12.

46. Graham, S.; Lewis, B.; Flanagan, B.; Watson, M.; Peipins, L. Travel by Public Transit to Mammography Facilities in 6 US Urban Areas. J. Transp. Health 2015, 2, 602-609. [CrossRef]

47. Delmelle, E.C.; Casas, I. Evaluating the Spatial Equity of Bus Rapid Transit-Based Accessibility Patterns in a Developing Country: The Case of Cali, Colombia. Transp. Policy 2012, 20, 36-46. [CrossRef]

48. Foth, N.; Manaugh, K.; El-Geneidy, A.M. Towards Equitable Transit: Examining Transit Accessibility and Social Need in Toronto, Canada, 1996-2006. J. Transp. Geogr. 2013, 29, 1-10. [CrossRef]

49. Melbye, D.C.; Møller-Jensen, L.; Andreasen, M.H.; Kiduanga, J.; Busck, A.G. Accessibility, Congestion and Travel Delays in Dar Es Salaam-A Time-Distance Perspective. Habitat Int. 2015, 46, 178-186. [CrossRef]

50. Berube, A.; Kneebone, E.; Puentes, R.; Tomer, A. Missed Opportunity: Transit and Jobs in Metropolitan America, Metropolitan Infrastructure Initiative Series and Metropolitan Opportunity Series. Brook. Inst. 2011, 5, 13.

51. Alonso, W. Location and Land Use. Toward a General Theory of Land Rent. Location and Land Use. Toward a General Theory of Land Rent; Harvard University Press: Cambridge, MA, USA, 1964.

52. Mills, E.S. Studies in the Structure of the Urban Economy; The Johns Hopkins Press: Baltimore, MD, USA, 1972.

53. Muth, R.F. The Spatial Pattern of Urban Residential Land Use, Cities and Housing; Cambridge University Press: Cambridge, UK, 1969.

54. Stokenberga, A. Does Bus Rapid Transit Influence Urban Land Development and Property Values: A Review of the Literature. Transp. Rev. 2014, 34, 276-296. [CrossRef]

55. Boarnet, M.G.; Chalermpong, S. New Highways, House Prices, and Urban Development: A Case Study of Toll Roads in Orange County, Ca. Hous. Policy Debate 2001, 12, 575-605. [CrossRef]

56. Lang, J.T.; O'Neill, K.M.; Hallman, W.K. Expertise, Trust, and Communication about Food Biotechnology. J. Agrobiotechnology Manag. Econ. 2003, 6, 4 .

57. Cervero, R.; Landis, J. Twenty Years of the Bay Area Rapid Transit System: Land Use and Development Impacts. Transp. Res. Part A Policy Pract. 1997, 31, 309-333. [CrossRef]

58. Glaeser, E. Cities, Productivity, and Quality of Life. Science 2011, 333, 592-594. [CrossRef] [PubMed]

59. Ewing, R.; Cervero, R. Travel and the Built Environment: A Meta-Analysis. J. Am. Plan. Assoc. 2010, 76, 265-294. [CrossRef]

60. Munishi, E.J. Rural-Urban Migration and Resilience Implications on the Maasai Households' in North- Eastern Tanzania. Afr. J. Appl. Res. 2019, 5, 24-44.

61. Litman, T. Well Measured: Developing Indicators for Sustainable and Livable Transport Planning; Victoria Transport Policy Institute: Victoria, BC, Canada, 2021.

62. Ward, J.H., Jr. Hierarchical Grouping to Optimize an Objective Function. J. Am. Stat. Assoc. 1963, 58, 236-244. [CrossRef]

63. Jeon, J.-H.; Kho, S.-Y.; Park, J.J.; Kim, D.-K. Effects of Spatial Aggregation Level on an Urban Transportation Planning Model. KSCE J. Civ. Eng. 2012, 16, 835-844. [CrossRef]

64. Zegras, C. The Built Environment and Motor Vehicle Ownership and Use: Evidence from Santiago de Chile. Urban Stud. 2010, 47, 1793-1817. [CrossRef]

65. Ratner, K.A.; Goetz, A.R. The Reshaping of Land Use and Urban Form in Denver through Transit-Oriented Development. Cities 2013, 30, 31-46. [CrossRef]

66. Li, G. China Urban Rail Transit Industry Development Report; China Railway Publications: Beijing, China, 2020. (In Chinese)

67. Lee, J.; Abdel-Aty, M.; Jiang, X. Development of Zone System for Macro-Level Traffic Safety Analysis. J. Transp. Geogr. 2014, 38, 13-21. [CrossRef] 
68. Litman, T. The Online TDM Encyclopedia: Mobility Management Information Gateway. Transp. Policy 2003, 10, 245-249. [CrossRef]

69. Robinson, P.L.; Dominguez, F.; Teklehaimanot, S.; Lee, M.; Brown, A.; Goodchild, M. Does Distance Decay Modelling of Supermarket Accessibility Predict Fruit and Vegetable Intake by Individuals in a Large Metropolitan Area? J. Health Care Poor Underserved 2013, 24, 172-185. [CrossRef]

70. Luo, W.; Wang, F. Measures of Spatial Accessibility to Health Care in a GIS Environment: Synthesis and a Case Study in the Chicago Region. Environ. Plan. B Plan. Des. 2003, 30, 865-884. [CrossRef]

71. Xu, W.; Ding, Y.; Zhou, J.; Li, Y. Transit Accessibility Measures Incorporating the Temporal Dimension. Cities 2015, 46, 55-66. [CrossRef]

72. Li, Z.; Han, Z.; Xin, J.; Luo, X.; Su, S.; Weng, M. Transit Oriented Development among Metro Station Areas in Shanghai, China: Variations, Typology, Optimization and Implications for Land Use Planning. Land Use policy 2019, 82, 269-282. [CrossRef]

73. Storper, M.; Scott, A.J. Rethinking Human Capital, Creativity and Urban Growth. J. Econ. Geogr. 2008, 9, 147-167. [CrossRef]

74. Wegener, M.; Fuerst, F. Land-Use Transport Interaction: State of the Art. SSRN Electron. J. 2004, 1, 19-22. [CrossRef]

75. Illingworth, P.J.; Groome, N.P.; Byrd, W.; Rainey, W.E.; McNeilly, A.S.; Mather, J.P.; Bremner, W.J. Inhibin-B: A Likely Candidate for the Physiologically Important Form of Inhibin in Men. J. Clin. Endocrinol. Metab. 1996, 81, 1321-1325. [PubMed]

76. Chen, N.; Qin, F.; Zhai, Y.; Cao, H.; Zhang, R.; Cao, F. Evaluation of Coordinated Development of Forestry Management Efficiency and Forest Ecological Security: A Spatiotemporal Empirical Study Based on China's Provinces. J. Clean. Prod. 2020, $260,121042$. [CrossRef]

77. Cong, I.; Choi, S.; Lukin, M.D. Quantum Convolutional Neural Networks. Nat. Phys. 2019, 15, 1273-1278. [CrossRef]

78. Fan, Y.; Fang, C.; Zhang, Q. Coupling Coordinated Development between Social Economy and Ecological Environment in Chinese Provincial Capital Cities-Assessment and Policy Implications. J. Clean. Prod. 2019, 229, 289-298. [CrossRef]

79. Cervero, R.; Kang, C.D. Bus Rapid Transit Impacts on Land Uses and Land Values in Seoul, Korea. Transp. Policy 2011, 18, 102-116. [CrossRef]

80. Montgomery, J. Making a City: Urbanity, Vitality and Urban Design. J. Urban Des. 1998, 3, 93-116. [CrossRef]

81. Sung, H.; Oh, J.-T. Transit-Oriented Development in a High-Density City: Identifying Its Association with Transit Ridership in Seoul, Korea. Cities 2011, 28, 70-82. [CrossRef]

82. Borgatti, S.P.; Everett, M.G. Models of Core/Periphery Structures. Soc. Netw. 2000, 21, 375-395. [CrossRef]

83. Xu, X.-Y.; Liu, J.; Li, H.-Y.; Jiang, M. Capacity-Oriented Passenger Flow Control under Uncertain Demand: Algorithm Development and Real-World Case Study. Transp. Res. Part E Logist. Trans. Rev. 2016, 87, 130-148. [CrossRef] 